\title{
THE KUWAITI BUSINESS ENVIRONMENT AND HUMAN CAPITAL DEVELOPMENT: STRATEGIC HIGHLIGHTS
}

\author{
Lyudmila MIHAYLOVA ${ }^{a *}$, Saad ALANSSARI ${ }^{b}$, Emil PAPAZOV ${ }^{c}$ \\ a,b,c University of Ruse “Angel Kanchev”, Bulgaria
}

DOI: $10.24818 / \mathrm{IMC} / 2020 / 03.06$

\begin{abstract}
Managing organizations in an exceedingly dynamic business environment could be a vital issue. The aim of the paper is to analyse some aspects of the Kuwaiti business environment and assess its strategic importance for organizations' development. The focus is on human capital problems as a key factor to success. Understanding the needs of the human capital along with the constant target to implement new measures in this field has been a governmental priority in the state of Kuwait, especiallywith regard to education and literacy level, which in Kuwait remained relatively constant or even slightly increased. On the basis of literature review and statistical data analysis, some ideas for future improvements in the domains of education, housing, employment, and pensions system as part of the business environment are shared.
\end{abstract}

KEYWORDS: Business Environment, Strategic Implications, Human Capital Development

\section{INTRODUCTION}

Business environment consists of various components and factors influencing the development of every economy. Some of them are external to the organization and include a number of macro- and microaspects of the socio-economic development. They are usually analysed in different directions, including political, economic, socio-cultural, and scientific-technical context (Laouiti et al., 2014; Atanassov et al., 2017).

The aim of this paper is to comment on some important socio-economic aspects of the Kuwaiti business environment and highlight their significance for organizations' strategic development. Among them stand out policies, most of which are planned and implemented by the State of Kuwait. They are aimed at improving the environment for human capital development based on better educational, employment, housing and retirement perspectives. The ultimate goal of the investigation is to offer ideas for raising the level of skilled workforce through expanding knowledge and creating reasonable stimuli in this direction. The reason for this focus is that nowadays the key to success of any organization lies in its human capital as it is the only one capable of finding unique and creative solutions when facing threats coming from the environment (Nastase et al., 2019).

Besides, human capital as part of the internal environment of a business, depends on the level of education and the other external factors mentioned above. Additional questions that are only hinted in this paper, are: "What is the influence of national factors such as culture, government policy and education systems on national patterns of human capital management?” (Budhwar \& Debrah, 2013), and“Constitutes the human factor the 'centre stage' to business competitiveness?” (Hunter \& Saunders, 2005).Understanding the needs of the human capital along with the constant focus on

\footnotetext{
${ }^{*}$ Corresponding author. E-mail address: Imihaylova777@gmail.com
} 
implementing new measures to improve its condition should be one of the most important political priority.

To achieve the set goal, this paper uses the methods of literature review and statistical data analysis. The latter is especially useful when presenting the literacy level in connection with possible future policies in this field.

A recent statistics of the Central Bureau of Statistics dated February 2019 (https://csb.gov.kw, May 19, 2019) regarding employment in the governmental sector in Kuwait has shown that the literacy rate of employed Kuwaiti citizens is at a high level, as only $12.3 \%$ of the people have no high school diploma, whereas $18.7 \%$ have a high school diploma and $46.9 \%$ possess a Bachelor's Degree. The illiteracy rate among Kuwaitis is $0.1 \%$. With constantly increasing literacy rates and with more and more Kuwaitis obtaining Bachelor's degrees and studying abroad on scholarships offered by the Ministry of Higher Education of the State of Kuwait, not only does the number of holder Bachelor's Degrees increases, but also the qualifications acquired tend to be more and more diverse, in an attempt to make up for the gap between the Kuwait's actual skill needs and the existing skills among Kuwaiti nationals. This is a clear sign that the undertaken efforts by the Government of Kuwait are largely efficient, which does not exclude the possibility to propose and implement additional measures to improve the situation in this direction.

\section{ANALYSIS OF THE EFFECTS OF THE MEASURES IMPLEMENTED BY THE GOVERNMENT OF THE STATE OF KUWAIT}

One of the means of reducing the country's need of skilled workforce from outside the country is the coordinated policy of the Ministry of Labour and Higher Education, worked out with the help ofthe local academia. The task is to permanently identify the market needs and therefore, the required skills. For instance, if the country's needs for health care professionals is at elevated level, then national programs to raise public awareness among Kuwaiti nationals should be implemented in addition to scholarships in that field which should be offered to Kuwaiti students. Investing in the nation's human capital will eventually pay off and highly sought-after job encouragement allowances should be considered.

Using the above-mentioned thesis, should the need for heart surgeons, for instance, be at high level in Kuwait, then Kuwaiti surgeons should be given a much-needed profession allowance. In this way, the country will ensure that its citizens get the skills much needed by the market, in addition to using its workforce for occupying existing jobs, and thus reducing the extent to which it depends on foreign employees.

Money allowances are always the best stimulant, and each profession should be constantly analysed in terms of market needs and therefore be assigned a monthly allowance value. This periodical analysis in keeping with the market's actual trends is the only way of assessing the needs which can be translated into specializations abroad or certifications of existing national assets. And since science is always evolving, periodic specialization courses should be offered to Kuwaiti nationals to update their knowledge constantly and properly and therefore their skills.

During the last decade, the number of skilled Kuwaiti professionals has increased and it is good to read in the daily local news that more and more Kuwaitis are becoming well known surgeons, dentists, architects, bakers, chefs, entrepreneurs, etc., and this is not only good for the economy, but also for increasing national pride and establishing a sense of self-assuredness that local resources are on the right track and that once oil reserves stop accounting for most of the country's Gross Domestic Product. The information about Gross Domestic Product of Kuwait is given below (Table 1), (https://www.csb.gov.kw, August 30, 2020). 
Table 1. Percentage Distribution of Quarterly Gross Domestic Product at Current and Constant Prices (Q1 2019-2020), (Million KWD)

\begin{tabular}{|c|c|c|c|c|c|c|c|c|}
\hline \multicolumn{4}{|c|}{2020} & \multicolumn{4}{|c|}{2019} & \multirow{3}{*}{$\begin{array}{c}\text { Kind of economic } \\
\text { activity }\end{array}$} \\
\hline \multicolumn{2}{|c|}{ Constant } & \multicolumn{2}{|c|}{ Current } & \multicolumn{2}{|c|}{ Constant } & \multicolumn{2}{|c|}{ Current } & \\
\hline Value & $\%$ & Value & $\%$ & Value & $\%$ & Value & $\%$ & \\
\hline 5277.9 & 54.2 & 3702.0 & 40.3 & 5215.0 & 53.0 & 4455.1 & 44.2 & Oil sector \\
\hline 4468.0 & 45.8 & 5494.5 & 59.7 & 4630.2 & 47.0 & 5631.7 & 55.8 & Non-oil sectors \\
\hline 45.0 & 0.5 & 48.1 & 0.5 & 43.1 & 0.4 & 45.5 & 0.5 & $\begin{array}{l}\text { Agriculture and } \\
\text { fishing }\end{array}$ \\
\hline 5277.9 & 54.2 & 3702.0 & 40.3 & 5215.0 & 53.0 & 4455.1 & 44.2 & $\begin{array}{l}\text { Extraction of crude } \\
\text { petroleum, natural gas } \\
\text { and service activities } \\
\text { incidental to oil and } \\
\text { gas }\end{array}$ \\
\hline 609.7 & 6.3 & 650.6 & 7.1 & 586.4 & 6.0 & 631.3 & 6.3 & Manufacturing \\
\hline 208.1 & 2.1 & 152.8 & 1.7 & 199.4 & 2.0 & 174.4 & 1.7 & $\begin{array}{l}\text { Electricity, gas and } \\
\text { water }\end{array}$ \\
\hline 212.7 & 2.2 & 305.2 & 3.3 & 224.3 & 2.3 & 329.5 & 3.3 & Construction \\
\hline 339.8 & 3.5 & 416.2 & 4.5 & 308.4 & 3.1 & 371.3 & 3.7 & $\begin{array}{l}\text { Wholesale and retail } \\
\text { trade }\end{array}$ \\
\hline 79.4 & 0.8 & 96.4 & 1.0 & 85.7 & 0.9 & 105.7 & 1.0 & Hotel and restaurant \\
\hline 237.0 & 2.4 & 299.7 & 3.3 & 262.2 & 2.7 & 296.8 & 2.9 & Transport \\
\hline 274.6 & 2.8 & 279.8 & 3.0 & 312.2 & 3.2 & 305.6 & 3.0 & Tele \\
\hline 805.3 & 8.3 & 968.0 & 10.5 & 809.7 & 8.2 & 933.7 & 9.3 & $\begin{array}{l}\text { Financial } \\
\text { intermediation }\end{array}$ \\
\hline 954.9 & 9.8 & 1144.1 & 12.4 & 943.6 & 9.6 & 1158.1 & 11.5 & Other services \\
\hline 1018.6 & 10.5 & 1016.1 & 11.0 & 1082.8 & 11.0 & 1073.2 & 10.6 & $\begin{array}{l}\text { Public administration } \\
\text { and defense }\end{array}$ \\
\hline 363.0 & 3.7 & 520.1 & 5.7 & 438.5 & 4.5 & 648.8 & 6.4 & Education \\
\hline 284.7 & 2.9 & 383.2 & 4.2 & 283.9 & 2.9 & 382.7 & 3.8 & Health and social work \\
\hline 100.1 & 1.0 & 147.4 & 1.6 & 97.1 & 1.0 & 144.0 & 1.4 & $\begin{array}{l}\text { Household with } \\
\text { Employed Persons }\end{array}$ \\
\hline 10305.3 & 105.7 & 9552.5 & 103.9 & 10381.3 & 105.4 & 10497.0 & 104.1 & GDP at basic prices \\
\hline-559.4 & -5.7 & -356.0 & -3.9 & -536.1 & -5.4 & -410.2 & -4.1 & $\begin{array}{l}\text { plus: Taxes less } \\
\text { subsidies on products }\end{array}$ \\
\hline 9745.9 & 100.0 & 9196.5 & 100.0 & 9845.2 & 100.0 & 10086.8 & 100.0 & $\begin{array}{l}\text { GDP at market's } \\
\text { values }\end{array}$ \\
\hline
\end{tabular}

The existing skilled human resources will find ways of supporting the country, since expanding knowledge is the best way to anticipate future market changes.

The employment of young graduates is and should be strongly related to that of education. It is the Government's duty to ensure that its citizens have proper access to education, as well as suitable employment options.

For the past decade, Kuwait has been dealing with a strong public sector oversaturation, as well as with a strong reliance on foreign workforce. Most Kuwaitis choose to work in the governmental 
sector, which in such cases offers inadequate employment, namely people are employed to fill positions without sufficient amount of work to do, and this unproductive participation is, in our opinion, the first major step the Government should take towards work efficiency. Jobs in the governmental sector should only be assigned based on necessity and skills, and unskilled employees should either be reassigned or sent to get the required skills.

Another factor which is meant to help young graduates (but which sometimes has proven to be doing the exact opposite) is the monthly unemployment support allowance. Given the fact that it has reached from $200 \mathrm{KWD}$ in 2006 to $800 \mathrm{KWD}$ in 2019, and is expected to increase in the coming years as well, most young graduates who are not married and who continue to live with their parents, choose to stay at home and take this monthly allowance, which is more than enough to cover their expenses (Table 2).

According to government officials, the lack of suitable employment options is not the young graduate's fault, and until proper employment opportunities are available. The young graduate is entitled to a monthly allowance calculated to cover the basic expenses until finding proper employment.

Table 2. Monthly unemployment support fees based on marital status and educational level

\begin{tabular}{|c|l|c|c|}
\hline \multirow{2}{*}{ № } & \multicolumn{1}{|c|}{ Educational Level } & \multicolumn{2}{|c|}{$\begin{array}{c}\text { Monthly Unemployment Support Fees } \\
\text { Based on Marital Status (KWD*) }\end{array}$} \\
\cline { 3 - 4 } & \multicolumn{1}{|c|}{ Single } & Married \\
\hline 1 & University degree or equivalent & $190 \mathrm{KWD}$ & $278 \mathrm{KWD}$ \\
\hline 2 & $\begin{array}{l}\text { College degree + training period of at } \\
\text { least 2 years }\end{array}$ & $169 \mathrm{KWD}$ & $250 \mathrm{KWD}$ \\
\hline 3 & $\begin{array}{l}\text { High school degree + 1 year of training or } \\
\text { Middle school degree + 3 years of period }\end{array}$ & $161 \mathrm{KWD}$ & $242 \mathrm{KWD}$ \\
\hline 4 & $\begin{array}{l}\text { High school degree or middle school } \\
\text { degree + training period of at least 1 year }\end{array}$ & $147 \mathrm{KWD}$ & $222 \mathrm{KWD}$ \\
\hline 5 & High school degree & $141 \mathrm{KWD}$ & $141 \mathrm{KWD}$ \\
\hline 6 & Without high school degree & $136 \mathrm{KWD}$ & $211 \mathrm{KWD}$ \\
\hline
\end{tabular}

Source: Program of Restructuring the Labor Force of the State of Kuwait (2008), Law no. 19/2000

-Minimum Kuwaiti employment percentage within the private sector, Governmental issue, p.5.

*1 KWD = 2.78427 EUR, https://ec.europa.eu/info/funding-tenders/how-eu-funding-works/

Information-contractors-and-beneficiaries/exchange-rate-inforeuro_en, August 10, 2020

The terms mentioned above apply only to Kuwaiti citizens who are at least 18 and are no longer studying. They are neither supposed to have been employed in the past, nor registered with the Social Security Payment Department.

It is strongly believable that both the Government's and the citizen's employment philosophy need to change inasmuch as to understand that certain advantages should not be taken for granted. Job placing programs should continue to exist and should receive a much more interest on behalf of young graduates in search of a job. In addition to that, focused training and further education should be granted to those in search of a job. The perception of ethnic job roles has throughout the time placed Kuwaitis in the public job sector, associating most of the private jobs with foreign workforce. Then not only the reliance on foreign workforce will be reduced, but also the private sector jobs will become more appealing to young graduates. The young generations of Kuwaitis, most of who have studied abroad at the Ministry of Higher Education's expense, come back to Kuwait with a different work ethic, but this should also be supported by state and civil society decisions. 
Although unemployment in Kuwait is at a low level, it is convinced that in order for it to remain low, more and more young graduates should also consider accepting or applying for positions in the private sector as well, ensuring further economic prosperity and limiting the need for foreign workforce.

Increased entrepreneurship is also a method of stimulating young graduates into starting their own businesses, and the interest free loan granted by the Kuwaiti Government is allowing many of them to pursue their business ideas. Not only do they become employed, but they may also create more jobs with their businesses. For instance, in the case of a small bakery, not only the Kuwaiti behind the business idea will be an employee of the company created, but he might need additional help, and it is this particular need for help that creates new jobs, which, in the case of a bakery, may include additional bakers, cleaners and delivery personnel, etc.

Another important governmental measure meant to encourage the employment of local citizens is that of imposing a minimum percentage of Kuwaiti nationals employed in the private sector, along with the focus on latest market trends and identifying the qualifications and skills that these market trends require, in order to forward these results to employment guidance centres from Kuwait.

The above mentioned measures as well as the low unemployment rate among young graduates in Kuwait are a sign that the implemented governmental measures are efficient and should continue to be efficient by implementing changes in keeping with the latest employment market trends, as investing in one country's workforce is one of the best economy boosting measures any government should focus on.

Another important facility granted by the Kuwaiti Government to all its citizens is the housing support, either in the form of a loan or monthly rent allowance, until accessing the housing loan.

However, certain analysts argue that Kuwait is dealing with a housing crisis and call for an alternative approach. The basic mistake made by the Kuwaiti Government is that of treating all its citizens as equal, and this is not the correct way of creating social equality. The upper class and therefore extremely wealthy families should not have received help from land distribution and house building loans in the past, and neither should they benefit from all the housing facilities in the future. They claim that since everyone profited from the land distribution and house allocation, this showed opportunity seizing by all citizens, no matter their wealth. It can be said that there is a grain of truth in this, as many other people in need of a house would have been able to benefit from all the governmental measures sooner, provided that those who could have afforded purchasing a house using their own money had not registered in the land distribution process. These analysts are right up to a certain point, but we think that the issue at stake is a much larger one. Citizens depend too much on the state for resource distribution, and given the Kuwaiti Government's rather generous welfare policies, a complete state reliance may not be the best strategy in the long run, as oil reserves will eventually become scarce and the economy will have to find alternative income-generating fields. However, a proper credit should be given to the Kuwaiti Government for providing housing support and granting housing facilities to its citizens, irrespective of their income, as opposed to other governments across the globe. Not only does it offer several alternatives to its citizens in view of fulfilling the social equality goal, which may not please everyone, but is nonetheless an extremely important issue.

Despite the social equality the Government is interested in keeping, there is an obvious inequality in terms of housing needs and wealth among Kuwaiti nationals. However, all should be given a chance to benefit from the governmental facilities. As incorrect as this may seem to some people, including citizens of the country, less passive housing regulations in keeping with the actual needs of the citizens may be taken into consideration by government officials, and it is certain that appropriate measures will be identified and implemented in the future.

Another facility granted by the Kuwaiti Government to its citizens is represented by the complex pensions system. Not only are the pension contributions extremely low, but also the retirement age is among the lowest in the world, not only in the Gulf countries. Yet again due to the high oil revenues, 
the Kuwaiti Government has managed to afford granting these amazing facilities to all its citizens, and yet again people have argued that this creates an unsustainable living model. Indeed, in the long run it will be unsustainable, unless people's approach towards the importance of seeking proper education and employment will change in the future. In addition to that, people should be more grateful for all the help received from the Government, either in the form of a scholarship, or business starting loan, or a house allowance, and stop relying solely on it. The Government's welfare policy not only allows its citizens constant development, but it also offers them a certain level of comfort that many other governments across the globe will never offer, irrespective of the country's wealth.

\section{IDEAS FOR SOCIO-ECONOMICENVIRONMENT IMPROVEMENTS}

Based on the explanatory analysis in the previous paragraph, we suggest the following summary of achievements and facts (Table 3) that characterize each of the four domains, and also some ideas of what to be done in the near future in the government policies and measures so that to increase the efficiency of those policies. Each society forms its own values (Gankova-Ivanova, 2014) and indicators for business environment (Stanković et al., 2015).

Table 3. Summary of achievements, facts, and ideas in the four domains

\begin{tabular}{|c|c|c|}
\hline Area & Achievements / Facts & Ideas for the future \\
\hline \multirow[t]{2}{*}{ Education } & $\begin{array}{l}\text { Literacy level slightly } \\
\text { increased in the past } \\
\text { decade }\end{array}$ & $\begin{array}{l}\text { - Continuing the existing governmental measures that } \\
\text { proved successful. }\end{array}$ \\
\hline & $\begin{array}{l}\text { A gap between the } \\
\text { Kuwait's actual skill } \\
\text { needs and the existing } \\
\text { skills among Kuwaiti } \\
\text { nationals }\end{array}$ & $\begin{array}{l}\text { - Reducing the country's need of skilled workforce } \\
\text { from outside of the country on the basis of } \\
\text { permanently identifying the market needs and the } \\
\text { required skills. } \\
\text { - Periodic specialization courses offered to Kuwaiti } \\
\text { nationals. } \\
\text { - Each profession should be constantly analysed in } \\
\text { terms of market needs and therefore be assigned a } \\
\text { monthly allowance value. }\end{array}$ \\
\hline \multirow[t]{5}{*}{ Employment } & $\begin{array}{l}\text { A strong public sector } \\
\text { oversaturation }\end{array}$ & $\begin{array}{l}\text { - Jobs in the governmental sector should only be } \\
\text { assigned based on necessity and skills, and } \\
\text { unskilled employees should either be reassigned or } \\
\text { sent to get the required skills. }\end{array}$ \\
\hline & $\begin{array}{l}\text { A strong reliance on } \\
\text { foreign workforce }\end{array}$ & $\begin{array}{l}\text { - Imposing a minimum percentage of Kuwaiti } \\
\text { nationals employed in the private sector. }\end{array}$ \\
\hline & $\begin{array}{l}\text { Excessive monthly } \\
\text { unemployment support } \\
\text { allowance for young } \\
\text { graduates }\end{array}$ & $\begin{array}{l}\text { - Increased entrepreneurship, interest free loan } \\
\text { granted by the Kuwaiti Government. }\end{array}$ \\
\hline & $\begin{array}{l}\text { Lack or suitable } \\
\text { employment options for } \\
\text { young graduates }\end{array}$ & $\begin{array}{l}\text { - Focused training and further education should be } \\
\text { granted to those in search of a job. }\end{array}$ \\
\hline & $\begin{array}{l}\text { Perception of ethnic job } \\
\text { roles }\end{array}$ & $\begin{array}{l}\text { - Increasingly, young graduates should also consider } \\
\text { accepting or applying for positions in the private } \\
\text { sector as well. }\end{array}$ \\
\hline
\end{tabular}




\begin{tabular}{|c|c|c|}
\hline Area & Achievements / Facts & Ideas for the future \\
\hline \multirow[t]{3}{*}{ Housing } & $\begin{array}{l}\text { Treating all citizens as } \\
\text { equals, may not be the } \\
\text { correct way of creating } \\
\text { social equality }\end{array}$ & $\begin{array}{l}\text { - Less passive housing regulations in keeping with } \\
\text { the actual needs of the citizens may be taken into } \\
\text { consideration by government officials. }\end{array}$ \\
\hline & $\begin{array}{l}\text { Citizens depend too } \\
\text { much on the state for } \\
\text { resource distribution }\end{array}$ & - Promotion of entrepreneurship. \\
\hline & $\begin{array}{l}\text { In the long run, oil } \\
\text { reserves will eventually } \\
\text { become scarce }\end{array}$ & $\begin{array}{l}\text { - Shifting from resource-based to knowledge-based } \\
\text { economy by fostering new industries, attracting } \\
\text { R\&D companies. }\end{array}$ \\
\hline \multirow[t]{4}{*}{$\begin{array}{l}\text { Pensions } \\
\text { system }\end{array}$} & $\begin{array}{l}\text { The pension } \\
\text { contributions are } \\
\text { extremely low }\end{array}$ & $\begin{array}{l}\text { - Adjusting the pension system, for example by } \\
\text { increasing the social security taxes for incomes } \\
\text { from abroad. }\end{array}$ \\
\hline & $\begin{array}{l}\text { The retirement age is } \\
\text { among the lowest in the } \\
\text { world }\end{array}$ & $\begin{array}{l}\text { - People's approach towards the importance of } \\
\text { seeking proper education and employment should } \\
\text { change in the future. } \\
\text { - People should stop relying solely on governmental } \\
\text { support. }\end{array}$ \\
\hline & Complex system & \multirow[b]{2}{*}{$\begin{array}{l}\text { - Neither the retirement age nor the pension } \\
\text { contributions should be reduced to start appreciating } \\
\text { the facilities granted more and therefore } \\
\text { acknowledge the necessity to work in order to be } \\
\text { granted further benefits, such as pensions. Further } \\
\text { such reductions will be completely unsustainable, } \\
\text { unless the country finds new income generating } \\
\text { sources, such as foreign investments. }\end{array}$} \\
\hline & $\begin{array}{l}\text { Offers a great level of } \\
\text { financial comfort to } \\
\text { retired Kuwaitis }\end{array}$ & \\
\hline
\end{tabular}

Source: Authors' own analysis

All the four aspects presented in the paragraphs above are interrelated. Housing strategies cannot be properly sustained without carefully considering employment and education security, and immediate solutions should not be the focus on the Government, but solutions that will last for generations. Governmental support is extremely essential in maximizing the potential of a country's human resources, and so is the involvement and aspiration towards continuous progress of its citizens. Efficiency should remain one of the key aspects in determining and implementing future governmental measures or approaches in the four human resources fields mentioned above, in keeping, of course, with the latest economic trends. Long term solutions or strategic solutions (Papazov \& Mihaylova, 2015; Papazov, 2014; Cicea et al., 2019) should be sought, as opposed to immediate solutions, as oil revenues are becoming scarce and apart from foreign investments, investing in a country's human resources can help boost a country's economy and ensure both social and economic stability. The last ones are key factors for managing sustainable organizations (Kunev et al., 2017; Nicolescu \& Nicolescu, 2017; Hofbauer \& Bergmann, 2012).

In addition to the above mentioned, the citizens' aspirations are a result of state-induced rights, however these rights should be appreciated, and citizens should work towards first improving themselves professionally to be able to help their country thrive. Empowered citizens are, as far as itis concerned, the right strategy of tackling future ways of supporting the national economy, in view of the oil revenues that are expected to become scarce one day. The following quote perfectly 
sums up the present and future challenges of the Kuwaiti Government: "The future of urban development in the Gulf lies in human development. Over-dependence on oil and the belief that modernity equals infrastructure developments have distracted attention from human development which requires social, political, cultural, and academic restructuring.” (Ghabra, 2010, p. 109).

\section{CONCLUSIONS}

Challenges in the future stemming from the business environment require further investment in the country's human capital. Setting realistic aspirations for all citizens and creating significant assets and advantages in facing future economic trends is a must, as more and more economies develop under the influence of the human factor. It is the government's duty to continue focusing on developing its human resources, whereas it is the duty of the nation's citizens to acknowledge the role they play in ensuring the country's success and to strive for constantly improving themselves, inasmuch as personal improvements should be synonymous with national improvement. Only then will such governmental investments in its human capital pay off. Applying proper research methods, some ideas for future improvements in the domains of education, housing, employment, and pensions system as a part of business environment are brought out. Their eventual realization will contribute to raise the sustainability of the country's business.

\section{REFERENCES}

Atanassov, A., Trifonova, S., Saraivanova, J. \& Pramatarov, A. (2017). Assessment of the administrative burdens for businesses in Bulgaria according to the national legislation related to the European Union internal market. Management: Journal of Contemporary Management Issues, 22 (Special Issue), 21-49.

Budhwar, P. S. \& Debrah, Y. A. (2013). Human resource management in developing countries. New York, NY: Routledge.bu

Cicea, C., Popa, I., Marinescu, C. \& Ștefan, S. C. (2019). Determinants of SMEs' performance: evidence from European countries. Economic Research - EkonomskaIstraživanja, 32(1), 16021620.

Gankova-Ivanova, T. (2014). Open government, modernization of public administration and egovernment in Bulgaria. Journal of the Technical University of Gabrovo, 50, 60-89.

Ghabra, Sh. (2010). Modern Gulf Cities. In R. Koolhaas et al. (Eds.), Al Manakh. Amsterdam, Netherlands: Stichting Archis.

Hofbauer, G. \& Bergmann, S. (2012). Professionelles Controlling in Marketing und Vertrieb: Ein integrierter Ansatz. Erlangen, Germany: Publicis Publishing.

Hunter, I. \& Saunders, J. (2005). Transforming HR: How to get shared services, outsourcing and business partnering to deliver what you want. New York, NY: Thorogood.

Kunev, S., Kostadinova, I. \& Stoycheva, B. (2017). Business governance and corporate social responsibility in Bulgaria. Analele Universității "Eftimie Murgu” Resita. Fascicola II. Studii Economice. 24, 99-115.

Laouiti, R., Ghari, S. \& Liouane, N. (2014). The effect of business environment on firm performance Exploratory Study: Case of Tunisian enterprises. International Journal of Management \& Information Technology, 8(3), 1430-1439.

Nastase, M., Bibu, N., Munteanu, A. I., Mircioi, I. \& Florescu, M. S. (2019). The specific elements of strategic human resources management for competitive business development. Industria Textilă, 70(6), 579-586.

Nicolescu, O. \& Nicolescu, C. (2017). New Approach-Quadrangle of Knowledge Based Sustainability. International conference Knowledge-based organization, 23(1), 411-417). 
Papazov, E. \& Mihaylova, L. (2015). Organization of Management Accounting Information in the Context of Corporate Strategy. Procedia - Social and Behavioral Sciences, 213, 309-313.

Papazov, E. (2014). A "Reverse" Approach to Coordination of Strategic and Tactical Financial Decisions for Small Business Growth. Procedia - Social and Behavioral Sciences, 156, 161165.

Program of Restructuring the Labor Force of the State of Kuwait (2008). Law no. 19/2000 Minimum Kuwaiti employment percentage within the private sector, Governmental issue.

Stanković, J., Marković, I. \& Stojanović, M. (2015). Investment strategy optimization using technical analysis and predictive modeling in emerging markets. ProcediaEconFinance, 19(15), 51-62.

Central Kuwait Statistical Bureau. (n.d.). Retrieved May 19, 2019 from https://csb.gov.kw/Pages/Statistics_en?ID=13\& ParentCatID=1

Central Kuwait Statistical Bureau. (n.d.). Retrieved August 30, 2020 from https://www.csb.gov.kw/Pages/Statistics_en?ID=69\&ParentCatID=\%203[

European Commission. (n.d.). Retrieved August 10, 2020 from https://ec.europa.eu/info/fundingtenders/how-eu-funding-works/information-contractors-and-beneficiaries/exchange-rateinforeuro_en[

Gulf Business. (n.d.). Retrieved May 20, 2019 from https://gulfbusiness.com 